A4

doi: $10.14232 /$ fgykf.2018.a4

\title{
A Juncus gerardii fitokémiai vizsgálata
}

\author{
Stefkó Dóra, ${ }^{1}$ Barta Anita, ${ }^{1}$ Kúsz Norbert, ${ }^{1}$ Csorba Attila, ${ }^{1}$ Bakacsy László, ${ }^{2}$ \\ Szepesi Ágnes, ${ }^{2}$ Hohmann Judit, ${ }^{1}$ Vasas Andrea ${ }^{1}$
}

${ }^{1}$ Szegedi Tudományegyetem, Interdiszciplináris Kiválósági Központ, Farmakognóziai Intézet, 6720 Szeged Eötvös u. 6.

${ }^{2}$ Szegedi Tudományegyetem, Növénybiológiai Tanszék, 6726 Szeged, Közép fasor 52.

A Juncaceae család két legnagyobb nemzetsége a Juncus és a Luzula. A két genusz fajaiból korábban elsősorban terpenoidokat, flavonoidokat és fenantréneket azonosítottak, amelyek közül kiemelkedő jelentőségűek a figyelemre méltó biológiai aktivitással ( $\mathrm{pl}$. in vitro citotoxikus, antimikrobiális, antioxidáns és gyulladáscsökkentő hatás) és szerkezeti változékonysággal rendelkező fenantrének. A vegyületek legtöbbje vinilcsoporttal szubsztituált, ezen anyagok kemotaxanómiai szempontból is nagy jelentőséggel bírnak. A Juncaceae család ígéretes fenantrénforrás, azonban napjainkig a család fajainak alig több mint 1\%-át tanulmányozták fitokémiai és farmakológiai szempontból.

Munkánk során célul tűztük ki a korábban még nem vizsgált Juncus gerardii Loisel. metabolitjainak izolálását és szerkezetmeghatározását.

A szobahőmérsékleten szárított és aprított növényt metanollal perkolátorban extraháltuk. Betöményítést követően a kivonatot 50\%-os metanolban oldottuk és $n$ hexánnal, kloroformmal és etil-acetáttal folyadék-folyadék megosztást végeztünk. A fenantrének a $\mathrm{CHCl}_{3}$-os és az EtOAc-os frakciókban dúsultak fel, így ezekkel dolgoztunk tovább. A szerves fázisokból a vegyületek tisztítását többlépéses kromatográfiás eljárás segítségével végeztük, oszlopkromatográfia, vákuum folyadékkromatográfia, közepes nyomású folyadékkromatográfia, gélszúrés, preparatív vékonyréteg kromatográfia és nagy hatékonyságú folyadékkromatográfia alkalmazásával. A vegyületek szerkezetmeghatározása NMR és tömegspektroszkópiai módszerekkel, valamint irodalmi adatokkal való összevetéssel történt.

Munkánk eredményeként a J. gerardiiból 26 vegyületet azonosítottunk, amelyek közül 23 fenantrén (12 új természetes anyag), 2 flavonoid és 1 kumarinszármazék.

Köszönetnyilvánitás: A kutatást az Emberi Erőforrások Minisztériuma UNKP-18-3 kódszámú Új Nemzeti Kiválóság Programja és a 20391-3/2018/FEKUSTRAT program, valamint az NKFIH (K128963) támogatta.

Témavezető: Vasas Andrea 